\title{
National Defense University
}

\author{
National War College
}

\section{New Nuclear Conceptions:}

How We Have Changed the Way We Think About Nuclear Weapons and Why it Matters

\section{Warren Stern/Class of 1997}

Course 5605

Core Course: Military Strategy and Operations

Seminar Leader Col. L. Stutznem

Faculty Advisor Dr. Al Pierce 


\section{Report Documentation Page}

Form Approved

OMB No. 0704-0188

Public reporting burden for the collection of information is estimated to average 1 hour per response, including the time for reviewing instructions, searching existing data sources, gathering and maintaining the data needed, and completing and reviewing the collection of information. Send comments regarding this burden estimate or any other aspect of this collection of information,

including suggestions for reducing this burden, to Washington Headquarters Services, Directorate for Information Operations and Reports, 1215 Jefferson Davis Highway, Suite 1204, Arlington

VA 22202-4302. Respondents should be aware that notwithstanding any other provision of law, no person shall be subject to a penalty for failing to comply with a collection of information if it

does not display a currently valid OMB control number.

1. REPORT DATE

1997

4. TITLE AND SUBTITLE

New Nuclear Conceptions: how We Have Changed the Way We Think About Nuclear Weapons and Why it Matters

6. AUTHOR(S)

7. PERFORMING ORGANIZATION NAME(S) AND ADDRESS(ES)

National War College,300 5th Avenue,Fort Lesley J.

McNair,Washington,DC,20319-6000

9. SPONSORING/MONITORING AGENCY NAME(S) AND ADDRESS(ES)

12. DISTRIBUTION/AVAILABILITY STATEMENT

Approved for public release; distribution unlimited

13. SUPPLEMENTARY NOTES

14. ABSTRACT

see report

15. SUBJECT TERMS

16. SECURITY CLASSIFICATION OF:

a. REPORT

unclassified b. ABSTRACT

unclassified c. THIS PAGE

unclassified
3. DATES COVERED

00-00-1997 to 00-00-1997

5a. CONTRACT NUMBER

5b. GRANT NUMBER

5c. PROGRAM ELEMENT NUMBER

5d. PROJECT NUMBER

5e. TASK NUMBER

5f. WORK UNIT NUMBER

8. PERFORMING ORGANIZATION

REPORT NUMBER

10. SPONSOR/MONITOR'S ACRONYM(S)

11. SPONSOR/MONITOR'S REPORT

$\operatorname{NUMBER}(S)$

\begin{tabular}{c|c|l}
$\begin{array}{c}\text { 17. LIMITATION OF } \\
\text { ABSTRACT }\end{array}$ & $\begin{array}{c}\text { 18. NUMBER } \\
\text { OF PAGES }\end{array}$ & 19a. NAME OF \\
& $\mathbf{1 3}$ & \\
& &
\end{tabular}


It has become axiomatic to note that the world has changed with the demise of the Soviet Union. In the area of nuclear weapons, the shift has been particularly apparent The United States and Russia have agreed to massive reductions in nuclear deployments. More sıgnuficantly, several other nuclear and near nuclear nations have been willing to elıminate their nuclear weapons and accept international inspections of residual capabilities Furthermore, the US appears to be following a policy of devalung the role of nuclear weapons in international relations and several former high rankang defense officials have even urged that the superpowers elimmate their nuclear capabilities Although it is obvious that the world has been transformed, it is less apparent how the world has changed, that is, how the observed nuclear changes relate to the end of the cold war.

Rational models of national secunty decision-makıng would argue that the observed nuclear transformation is simply a reflection of the reduction in superpower tensions. These models would suggest that policy-makers have revised therr assumptions about the international environment and decided that the new threat environment is such that their national interests allow nuclear reductions. Bureaucratic models of decısion-makng would add that institutional interests have also played an important role in this transformation While the end of the cold war itself did provide a basis for altering nuclear postures, it is difficult to explain all of the observed nuclear changes based solely on a reduction in superpower tensions and institutional factors. Indeed, a review of the nuclear policies in the US reveals a pattern that is difficult to explain solely in terms of rational interest-driven strategy.

This essay argues that an understanding of nuclear policy-making requires the Inclusion of a less tangible factor -- a psychological factor -- which we will call the "nuclear conception "Such conceptions underle most nuclear polıcies and have likely always played a 
major role in nuclear strategies The key conclusion of the essay is that the changes currently apparent in the realm of nuclear policy are in part due to the fact that nuclear conceptions are in the process of fundamental change and these changes will have broader implications for US nuclear strategy. This change in concepton, while largely sparked by US-Soviet rapprochement, is deeper than the simple suspension of superpower ideological compettion

\section{Why Nuclear Conceptions}

When we refer to nuclear conceptions we are, at a basic level, referring to policymakers' notions or images of nuclear explosives. These notions exist apart from the secunty environment, but they are also affected by that environment They are in part preconceptions that form the international environment, and part reaction to the international environment. Conceptions are enture behef templates which can affect views such as what good nuclear weapons can accomplish, who should posses them, and what the risks of nuclear employment are

Humans approach few issues without preconceptions. This is particularly true in the case $\mathrm{cf}$ abstract issues such as nuclear energy and strategy Our minds are not blank slates on which a strategy can be logically etched Spencer Weart wrote in his history of nuclear energy, "modern thinkıng about nuclear energy employs ımagery that can be traced back to a time long before the discovery or radioactivity. .such thinking has less to do with current physical reality than with autonomous features of our society, our culture, and our psychology "1 Though Weart focuses his analysis on public attitudes toward nuclear electric energy and the precise nature of this nuclear imagery, his insight has important implicatıons for nuclear strategy For

${ }^{1}$ Spencer R Weart, Nuclear Fear A History of Images. Harvard University Press. Cambndge, MA, 1988, p 421 
If our thunkıng about nuclear energy is based less on its the physical reality than on our psychology, then nuclear strategies must also be also based largely on the subconscious beliefs As Henry Kıssinger has pointed out, nuclear strategy itself is based on essentrally psychological criteria Aside from two relatıvely minor detonations at the end of World War II, nuclear weapons have never been used in combat. Thus they have had an effect on international affarrs only because political leaders believe they do so. Or rather, because political leaders believe their adversanes believe they do

It is to be expected that preconceptions or basic belief structures would exert an extremely strong influence in circumstances where they cannot be tested. Since no one really knows how effective or nsky nuclear strategies are, preconceived ideas come to the forefront. Coln Gray wrote, "In the whole nuclear realm, for the most prominent case, theory has far outstropped evidence and common sense." Absent facts, a rational strategist relies on theory, but if a theory cannot be tested, the primary gundance likely comes from beliefs. What it takes to deter and what can be deterred by nuclear weapons have been a matter of theology as much as strategy.

The assertion that conceptions play an important role in nuclear policy is also supported by the fact that the nuclear weapons are not easily assimulated into conventional risk/reward decisıon-making and strategy development. The damage associated with a significant nuclear exchange would be so severe that it is questionable whether policy-makers can fully integrate the risks and moral issues associated with nuclear posturing in their policy decisions in the logical manner assumed by standard models of national security decisionmakıng. In the words of General Lee Butler, who's views we will discuss later, "we have yet to

\footnotetext{
${ }^{2}$ Colm S Grey, "The Influence of Space Power Upon History," Comparattve Strategy, 1996, Vol 15, p 293
} 
fully grasp the monstrous effects these weapons, that the consequences of their use defy reason ." The devastatıng power of nuclear weapons is simply a force humans have never dealt with before and likely a concept that evolution has not prepared us to comprehend It is a unique conceptual challenge

This is not to say that policy-makers are fluppant about nuclear risks, or have not reviewed science's best estumates of the results of a nuclear exchange Rather, the point is that the damage is so extensive that standard deductive planning associated with other weapons systems and strategies do not suffice. It is not at all clear that one can fully comprehend what it means to kull tens or hundreds of mullions of noncombatants, to kull a natıon, or rusk having a majotity of your population destroyed Simply put, when discussing a nuclear exchange, the risk/reward calculations assumed in rational models of national security strategy lose much of their meaning because in many cases, the risk becomes effectively infinite. This is relevant because when existing models of decision-making fail, other subconscious effects become more important

\section{Cold War Conceptions}

For most of the cold war, the conception of nuclear weapons was what one could call "nuclear optumism." This was the conception of nuclear weapons as inherently good. Though dangerous, nuclear weapons were viewed as capable of bringing the world peace through the threat of destruction Nuclear weapons were viewed as essential for national survival with the rewards of employment substantally outweighing the risks. To be clear, it is generally uncontested that the threat of destruction can deter and in certain cases compel an enemy. But, throughout much of the cold war, nuclear strategies assumed much more. Nuclear

\footnotetext{
${ }^{3}$ General Lee Butler, USAF Retıred, The State of the World Forum, National Press Club Remarks, Dec 4 1996
} 
weapons were assumed to have a quality of overall propnety that was not justified by real world evidence. This optımısm took two forms which we will call "controlled nuclear optrmusm" and "limited nuclear optımısm"

The Eisenhower and Nixon adminıstrations provide good examples of controlled nuclear opttmism. Both had a conception of nuclear weapons not only as virtuous but also as inherently controllable They assumed that it was reasonable to make nuclear threats and use nuclear weapons in a wide range of circumstances and that escalation of their use could be carefully controlled. Eisenhower's New Look Strategy emphasized the primary relıance on nuclear weapons to repel attack for a wide range of contingencies. According strategic historian John Lewis Gaddis, Eisenhower was willing to use or threaten to use nuclear weapons in any of a number of curcumstances -- a Soviet conventional force attack in Europe, a violation of the Korean armıstice, a decision to intervene directly in Indochina, or a Chinese communist assault on Quemoy and Matsu. ${ }^{4}$ Eisenhower's continued farth in this strategy arose from domestic fiscal restraints as well as his fundamental conception of nuclear weapons

This conception was also apparent in the Nixon administration Henry Kissinger had an image of nuclear weapons as a device whose employment could be carefully controlled. This was exhibited, for example, during the 1973 Middle East war when Kissinger ordered that the US nuclear alert status be raised to DefCon III in order to send a signal of resolve to the Soviet Union. ${ }^{5}$ The policy of using nuclear alert status to signal resolve assumes controllability of nuclear escalation It also presumes that the signal has credibility; that the Soviets would believe that the risk of nuclear conflict was high enough to concede to US wishes, but that, at the same tume, the risks of mutual annihılation are sufficiently low. It would be difficult to

\footnotetext{
${ }^{4}$ John Lewis Gaddıs, Strategies of Containment, Oxford Unıversity Press, Oxford, 1982, p 171

${ }^{5}$ Henry Kissunger, Years of Upheaval, Little Brown and Company, Boston, p 588
} 
justify this policy without a pre-existng image or conception of nuclear weapons that support the policy.

The Kennedy administration followed a conception of limited nuclear optimism While Kennedy shared a great deal of Eisenhower`s optımısm regardıng the stability that nuclear weapons bestowed, he gave top priority on decreasing reliance on these weapons. While the international environment had not changed substantially in the years between the two administrations, the Kennedy administration moved away from the Eisenhower's assumption that nuclear weapons were useful to deter limited aggression According to the Policy Planning Council in 1961, "In conditions of nuclear stalemate, inttatng a recourse to nuclear weapons is irrational. The threat to do so is only convincing if it comes from an opponent who has been driven to desperation." Kennedy had a much more limited view of what nuclear weapons could accomplish.

To be sure, there were important political, economic, and security rationales for policies chosen during the cold war And, as described above, there were important distunctions between policies followed. However, the distance between the international and domestic environments and the policies chosen had to be bridged by a conception. a fundamental fath in the overall propriety of nuclear weapons

\section{Return of an Old Conception Nuclear Anxiety}

General Lee Butler (USAF Retured) and General Andrew Goodpaster surprised many in the national security community in 1996 when, after spending most of their careers supporting US nuclear policies, they publicly urged that the US commit to the elimination of nuclear weapons. Therr rationale for this newly adopted strategy was that the risks associated

\footnotetext{
${ }^{6}$ John Lewis Gaddıs, Strategies of Contamment, Oxford University Press. Oxford, 1982, p 196.
} 
with the deployment and proliferation were simply too high and that the US was capable of leading the world to nuclear disarmament. Other defense experts who had previously rejected a commitment to disarmament as being contrary to US interests have also recently lent credibility to this new strategy.

This transformation appears somewhat confused as few of these nisks associated with nuclear deployments were created with the end of the cold war. Indeed, in certan cases, quite the opposite may be true. While the Russian nuclear threat may have subsided, its final status is not at all clear and Chinese nuclear capabilities are increasing, as are those of several other nations. The world has changed in an important way, but not in a fundamental way that would support General Butler's change of heart

What has changed is that General Butler and others have adopted a new conception of nuclear weapons In other words, underlying belief structures have shifted. In his words, "the terror-ınduced anesthesia which suspended rational thought" was removed. The end of US Soviet competition allowed a new conception to come to the forefront This is not strictly a ratıonal interest/nisk based strategy assessment. The threat and the conception interacted in a nonlinear way to create a new strategy Neither one alone can account for the observed changes.

This different conception is one we will call "nuclear anxiety". Nuclear anxiety emphasizes the deadly power of nuclear weapons and assumes the possibility of their use is real and the costs are intolerable. As the name implies, the conception is generally pessimistic about human control of nuclear weapons and attmbutes an evil nature to them. In a sense, this 1s the frankenstein model It assumes that humans have created a weapon (1.e. frankenstein 
monster) that they cannot control. This conception leads directly to the belief that the only way to deal with nuclear weapons is to munumize or elıminate their role in international affairs.

Nuclear anxiety is not completely new. Indeed, this conception has been held by many outside of policy curcles throughout most of the nuclear age It has appeared in government only for short periods of time, however The first was in the initıal years of the nuclear age. In that period, American policy-makers vacullated between nuclear optımism and nuclear anxiety. President Truman, for example, greeted the destruction of Hiroshima with the words "this is the greatest thing in history." In his message to Congress on October 3 1945, however, He called for "international arrangements lookıng, if possible, to the renunciation of the use and development of the atomic bomb "7 Secretary of State Acheson's first reaction was “...the atomic bomb is the most frightenung yet. If we can't work out some sort of organization of great powers, we shall be gone geese for fair " Secretary of War Stumson also vac1llated, but basically fixed on a conception of nuclear anxiety and urged sharıng scientufic information as a good faith gesture On the whole, in the first years of the nuclear age, nuclear weapons seem to have been viewed as a sinıster device, and nuclear abolition was pursued with surprising vigor, at least as compared to the subsequent efforts.

Once the cold war began in earnest, however, American and Russian polıcy-makers fixed on a conception of nuclear optimism Nuclear anxiety did not become a dommant conception again untl 1983, when President Reagan announced his strategic defense initıatuve and asserted that he wanted American scientısts "to give us the means of rendenng <nuclear> weapons impotent and obsolete" so that Americans could live "secure in knowledge that their

\footnotetext{
${ }^{7}$ James Chase, 'Sharing the Atom Bomb." Forelgn Affairs, Volume 75, No 1, January/February 1996, PP 129135

${ }^{8}$ James Chase, "Sharng the Atom Bomb", Foretgn Affairs, Volume 75. No 1, January/February 1996, PP 129132
} 
securnty did not rest on the threat of instant retalıation." While Ronald Reagan's Strategic Defense Intiatıve and early nuclear abolition proposals are generally consıdered to reflect opposite ends of the political spectrum, they both reflect the same conception.

What is important however, is not that General Butler has adopted this new conception, nor that it has appeared in the past. Rather, the critical point is that this conception appears much more broadly today than ever before And, this conception can help to explain many of the dramatic steps that have been witnessed in the past decade In the US, for example, accordıng Stephen Cambone and Patrick Garrity of the Center for Strategic and International Studies, while the US's Nuclear Posture Review recommended munor changes in US nuclear strategy, US actions point to a policy of devaluing or marginalızıng nuclear weapons. Accordıng to their work, if Clinton administration efforts succeed, "nuclear weapons will indeed be on their way to ultumate global extunction "9

Moreover, durnng the first 50 years of the nuclear age, no nation that possessed nuclear weapons were willing to yield this capability. However, in the past decade, several countries have slowed, halted or reversed their programs Ukraine, Belarus, and Kazakhstan have allowed the removal of nuclear weapons that they inhented with the breakup of the Soviet Unıon South Africa dismantled and allowed international inspection of the material from its stockple of nuclear weapons. Argentina and Brazil, both close to a nuclear weapons capability, agreed to bring into force the Treaty of Tlatelolco with the obligations to bilateral inspections Moreover, the international community through the UN has supported forced dismantlement and contınued inspection of Iraq's nuclear program Finally, 178 nations have

\footnotetext{
${ }^{9}$ Stephen A Cambone and Patrick Garnty, "The Future of LS Nuclear Policy," Survı al, vol 36, no 4, Winter 1994-1995, p 90
} 
agreed to the indefinite extension of Nuclear Nonproliferation Treaty, a step that was impossible during the cold war and the period of nuclear optmism.

These steps reflect a fundamentally different conception of nuclear weapons than was held by many for most of the cold war. For example, it was not untll 1970 that the above mentioned Treaty limitang the spread of nuclear weapons was brought into force. And even as onginally conceived, the term was not indefinite, but rather to be reconsidered 25 years after its conclusion. Moreover, when concluded, the Treaty was not supported by two nuclear weapons states (France and China), despite the fact that it preserved their right to possess nuclear weapons

Two caveats are needed here First, the nuclear conception argument is not universal. It cannot apply to all countries or all individuals. Many have not changed theur views at all with the end of the cold war. Moreover, in key countries such as Israel and India, the conception or attitude toward nuclear weapons appears unaltered Second, in each the above examples, one can point to incentives given for the nuclear disarmament or strong rationales for a change in nuclear policy. However, if nuclear weapons were viewed as inherently useful tools -- that 1s, a conception of nuclear opttmism -- it is unlikely that these rationales or incentives would have been sufficient. Moreover, in a world of nuclear optımism, it is unclear that these incentives would have been offered in the first place.

\section{Old Nuclear Conceptions and New Nuclear Straregies}

If nuclear strategies are formed based on nuclear conception and these conceptions are in a process of transition, then there are important implications for defense policies. There are both opportunities and threats On the one hand, there may be an opening for new International cooperative efforts to deal with nuclear weapons that are today considered 
unreahstıc. On the other hand, the operation and effectiveness of nuclear deterrence may be threatened

Nuclear anxzety may in fact be a self fulfillung concepton The chances of miscalculation are heightened when conceptions are in transition. For example, a conception of nuclear anxiety could lead nations that possess nuclear weapons to change declaratory policies. While nuclear nations have maintained a tradition of non-use, all have thus far held that under appropriate conditions, they would in fact use such weapons. This threat supports the nuclear deterrent. If nuclear anxiety leads nations to emphasize that a nuclear conflict is unthulkable, the deterrent will be weakened, even if the object of the deterrent is otherwise inclined to believe that the threat of nuclear use is real. The response may be provocative actions. In his 1953 essay Strategy in the Missle Age, Bernard Brodie urged against declaratory policies on the non-use of nuclear weapons because it is not possible to predict in advance exactly how one may act under adverse conditions, regardless of initral intent. This advice is still relevant today. At the same time, it is possible that, regardless of the declaratory policy of nuclear nations, other nations may not take nuclear threats seriously and the results may be equally catastrophic

Though the risk of nuclear use may be increased by the new and changing conception, cooperative efforts to limit nuclear dangers would be anded. Proposals that have been considered impractical for decades because of the need for intrusive monitoring or other cooperative requrements, or simply the will to pursue them, may in fact become more plausible. General Butler`s assertion that "a swelling global refrain will" convince nations to forgo nuclear weapons, though dramatically stated, may in fact be more realıstıc than it initrally appears. More likely though, we will see only a greater willungness on the part of nuclear 
nations to link their deployments to nonproliferation efforts and greater diplomatic and economic incentives for disarmament and penalties for nuclear acquisition. We may see, for example, a culture which supports efforts to strike nuclear facilities of selected nations of nonproliferation concern. At the same tume, former President Reagan's vision of international cooperative efforts to develop effective national ballistic missle defense capabilities may become more than rhetoric (though physical realities will likely ensure that its does not become a reality)

Conclusion

Nuclear weapons have exusted only durnng a very unique period in international relations -- the cold war. All human thought concerning these weapons was formed during this particular period. It should not be surprising then, that when this period ended, basic human conceptions would change. This essay has argued that human conceptions and the environment interact in a nonlınear way to offer nuclear policy, or what is sometımes called nuclear strategy To some extent, conceptons or belief structures surround all new weapons The difference with regard to nuclear weapons is that these belief structures cannot be tested, and thus the conceptions perpetuate unchecked. We have not speculated on the source of these human conceptions or their likely course Nor have we addressed which conception is the "right" one The key point is to recognize that policies are based on these conceptions, and that new threats and opportunities may be offered as these conceptions change 